\title{
Open-back Shoes from the Southern Crypt in Piaseczno, Pomerania Province
}

\section{Introduction}

In 2017, research was conducted in the Church of the Nativity of the Blessed Virgin Mary in Piaseczno ${ }^{1}$. The basic task of the team was to explore the crypt located under the floor of the Chapel of Our Lady of the Scapular (hereinafter referred to as the southern crypt) (Grupa et al. 2015: 15-16; Grupa 2019: 192-198). The coffins were rather scattered, and there were two heaps of rubble mixed with grave goods and wooden relics of coffins, marked as rubble heap I and rubble heap 2. Under a bricked-in ventilation hole (the southern wall of the crypt), there was much rubbish thrown inside for at least two centuries. The situation was similar in the crypt under the chancel explored a year earlier (Grupa 20I8: 33). As a result, some of the grave goods were outside the coffins and it was difficult to match the artefacts found to specific burials. The main task of archaeologists and anthropologists was to separate human remains from rubbish and grave goods.

The open-back shoes presented below were only completed after restoration carried out in the Laboratory of Monument Conservation of the Nicolaus Copernicus University in Torun. Each shoe was found in a different part of the crypt: one between rotten wooden joists, under coffin no. 7, while the other one in the rubble heap no. 2 near the southern wall. The main aim of the analysis carried

I It was carried out by MA and PhD students of the Institute of Archaeology of the Nicolaus Copernicus University. It was the second research season. 
out at the time was to determine the basic function of the shoes: whether they were protective or house shoes, or if perhaps they served both these functions.

\section{The development of open-back footwear}

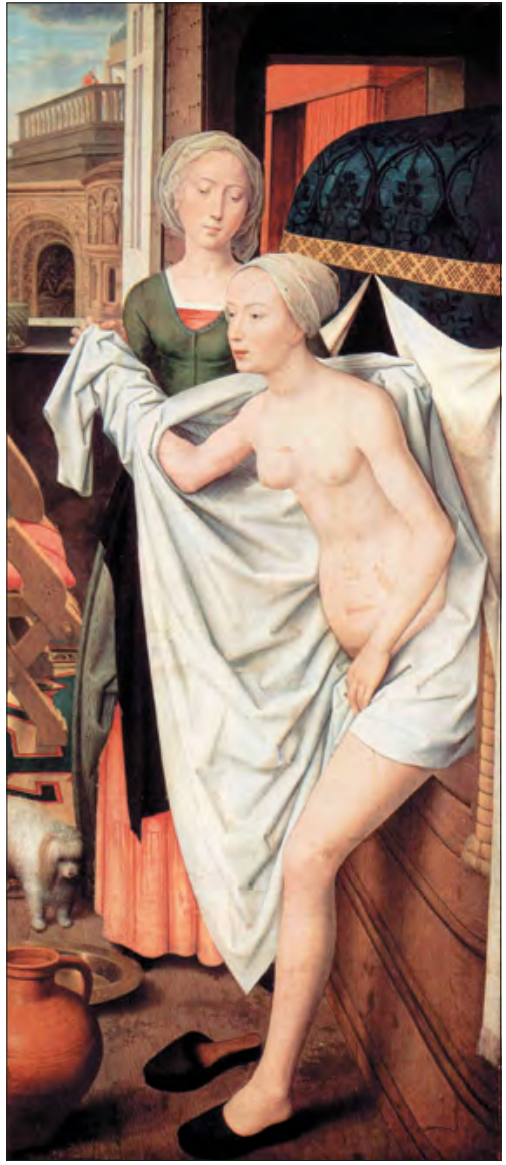

The history of open-back footwear was described by costumists and archaeologists at least from the second half of the twentieth century (Gutkowska-Rychlewska 1968: 35; Turnau 1983: 96, 98-99; Cnotliwy 1994: Fig. 5.2, 5.3; Wywrot-Wyszkowska 2002: Fig. I; 2008: 54-56; Ceynowa 2004: Fig. 2; 2005: Fig. 4). The earliest artefacts of this kind date back to the thirteenth century (Drążkowska 20II: IIs). However, at the time, these were overshoes worn outdoors, put on cloth leggings ${ }^{2}$ or leather shoes. They were called pattens, and their structure was simple. A sole with high supports was carved from a block of softwood ${ }^{3}$, and a leather upper was attached to it with iron nails, approximately $2 \mathrm{~cm}$ long ${ }^{4}$. The upper could be one- or two-part, and the structure was in some cases supplemented with a leather toe (Ceynowa 2004: I4I-I45; Każdy krok... 2016: 77-80, 84-85). Over time, the structure was modified and the

Fig. 1. Bathsheba in the Bath Hans Memling c. I480, https://en.wikipedia.org/wiki/ Bathsheba_(Memling)\#/media/File:Hans_ Memling_009.jpg (access I6 IV 2020).

2 The sole of cloth leggings was frequently reinforced by an additional layer of cloth or a leather sole (Zimmerman 2007: 349-352; Grupa 20I2: 237).

3 The dendrological research carried out by the Torun team indicate that the most often used species were lime, willow, and birch. This probably resulted from the availability of the material on the market.

4 The Authors' own research. Nails of this length were used in pattens found during research at 3a Panieńska Street (research carried out in 2007 by Lidia GrzeszkiewiczKotlewska) and on Granary Island (research carried out in 2016 by Renata Wiloch-Kozłowska). 
next pattens (in the fifteenth century) were leather, with uppers and soles made of leather. Between the layers of the sole of such footwear there was a cork or wooden insulation layer (Ceynowa 2009: 99). Their uppers were open unlike in the case of mules that developed at the same time. Mules had uppers that usually covered toes and the whole instep (Kazdy krok... 2016: I03-IIO), thanks to which shoes stayed safely on feet and people could walk freely. An additional insulation layer of wood or cork in a leather sole muffled the loud clack on stone or brick floors in rooms, which is probably why shoes of this type were also worn indoors. Moreover, the use of such a structure was perfect for thermal reasons, as it provided insulation against the floor that was always cold. This simple solution considerably improved the standard of living of people inhabiting Renaissance castles and tenements. It seems that at the end of the fifteenth century and at the beginning of the sixteenth century, home shoes started to get distinguished from outdoor footwear. This is confirmed by medieval and Renaissance iconography showing women at their toilet, with leather pattens or mules on their bare feet (Fig. I). There are also representations with shoes of this type at the beds of the sleeping (Cassagnes-Brouquet 2009: 23). The three types of protective overshoes (wooden pattens, leather pattens, and mules) were used all over medieval Europe, which is confirmed by archaeological research (Grew, de Neergaard 200I: 9I-IOI; Goubitz et al. 200I: 243-266; Każdy krok... 2016: 103-IIO) and iconographic representations (Pescio 2017: 70-71, 98, I26, 1295). Over the following years, this footwear underwent many stylistic metamorphoses. Different names were used: clogs, pantables ${ }^{6}$, mules ${ }^{7}$, and in Polish seventeenth-century testaments - slippers. Slippers were mostly worn on high-top boots called baczmagi ${ }^{8}$ (Klint et al. 2018: 79, I07, I48). In this case, they should be treated as outdoor footwear with

5 These are mostly women presented in the privacy of their homes: $A$ Woman at her Toilet, 1659-1660, painted by Jan Steen, Amsterdam, Rijksmuseum; Woman Tearing a Letter, I63I, painted by Dirck Hals, Mainz, Mittelrheinisches Landesmuseum; Two Kinds of Games (Interior of an Inn), painted by Jan Steen, Amsterdam, Rijksmuseum; Woman Reading a Letter, 1662-1665, painted by Gabriel Metsu, Dublin, National Gallery of Ireland, and female nudes, the best example of which is Susanna, 1636, painted by Rembrandt, The Hague, Mauritshius.

6 In British written sources, the term mule only refers to sixteenth-century chopines with tall platforms. Shoes with a similar or identical form as the ones described in this paper were called slippers or pantables, which corresponds to the Polish term pantofle (Swann 1982: 22).

7 In the Western literature the terms mules and pantables are used interchangeably to describe shoes consisting of soles and uppers only covering the forefoot. Such shoes typically have a thicker front part than standard shoes (Goubitz et al. 20Ir: 243).

8 It is worth noting that shoes are virtually absent from last wills and testaments. They provide details of all kinds of clothes but there are no mentions of foot protection, except for stockings. Last wills and testaments from the Halych Land concerning baczmagi and slippers are rather unique. 


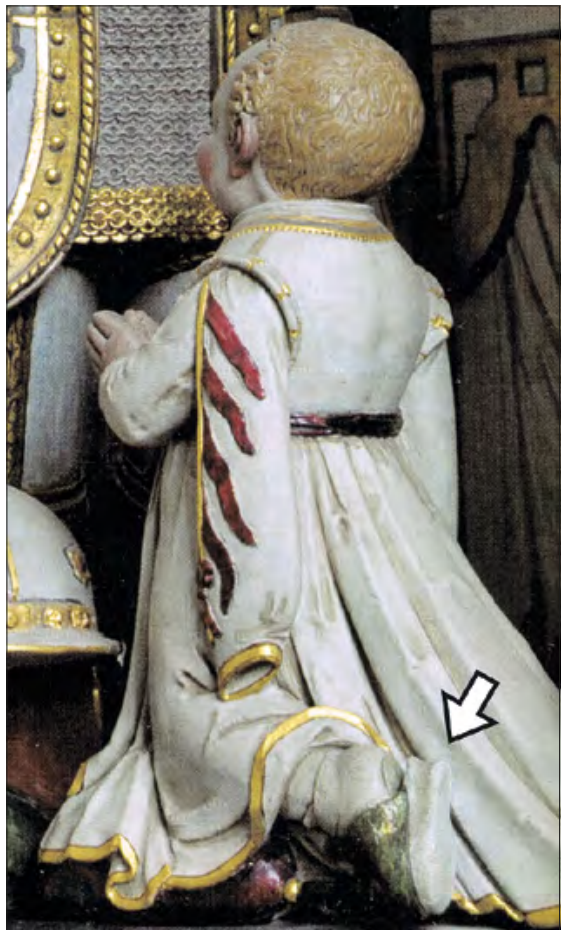

Fig. 2. A child's slipper from the grave of the Kos family in the Oliwa Cathedral (photograph by D. Grupa). a structure resembling low leather and wooden pattens. A perfect example of a slipper can be seen on the grave of the Kos family in the Oliwa Cathedral (Sikora, Szleszyński 20I4: 178). A small boy kneeling before the figures of Mikołaj (d. I599) and Andrzej Kos (d. 16I8) is wearing a leather boot above the ankle (with a medium top) and a green slipper with a deep upper ${ }^{9}$ (Fig. 2) on a thick sole in the form of a wedge (higher at the heel, lower at the toes). In such a case, it is difficult to say whether the inside of the sole was made of cork, softwood, or a combination of the two. What matters is the fact that the Polish dress included soft leather shoes with thick-soled slippers protecting the shoes against mechanical damage and ensuring thermal insulation against the ground. It cannot be excluded, however, that slippers at the time were multi-purpose footwear worn outdoors and/or indoors. A similar open-back shoe (made slightly higher with a layer of wood under the heel) was displayed at an exhibition Kazdy krok zostawia ślad (Every Step Leaves a Footprint) in the Archaeological Museum in Gdańsk (ref. no. MAG/GD/255/125/408).

Heels developed in the seventeenth century entailed other structural modifications to open-back shoes. Some shoes of this type were raised this way, which made squat slippers shapelier and slimmer. Others had their form adjusted so that

9 Perhaps this is the slipper structure mentioned in the last will and testament of N. Swaryczowski from 1636. Search in the territory of the Republic of Poland connected with the name of this type of footwear is very limited as it is hardly ever mentioned in last wills. N. Swaryczowski was a soldier from the Halych Land. Most probably, he was unmarried, which is why he informed the executors how he wanted to be dressed after his death. Apart from a scarlet satin jacket, a feryaz or a delia, crimson trousers, and a red satin cap with tails, he asked for boots or slippers (Klint et al. 20r8: I48). If both these names are mentioned, then boots were riding boots, which in the Polish army had high tops, whereas slippers should be treated as home open-back shoes or multi-purpose shoes that could also be worn over high boots. Perhaps this name was only associated with men's footwear. 


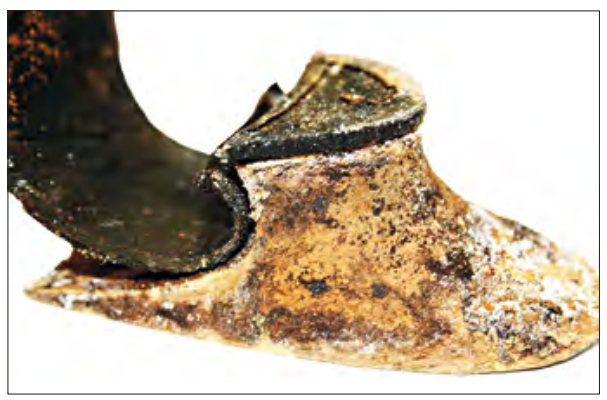

Fig. 3. Bytom Odrzański. A wooden heel with a thick, stiff sole (photograph by D. Grupa).

Fig. 4. Piaseczno. The left shoe right after it was found (photograph by A. Zamorowska).

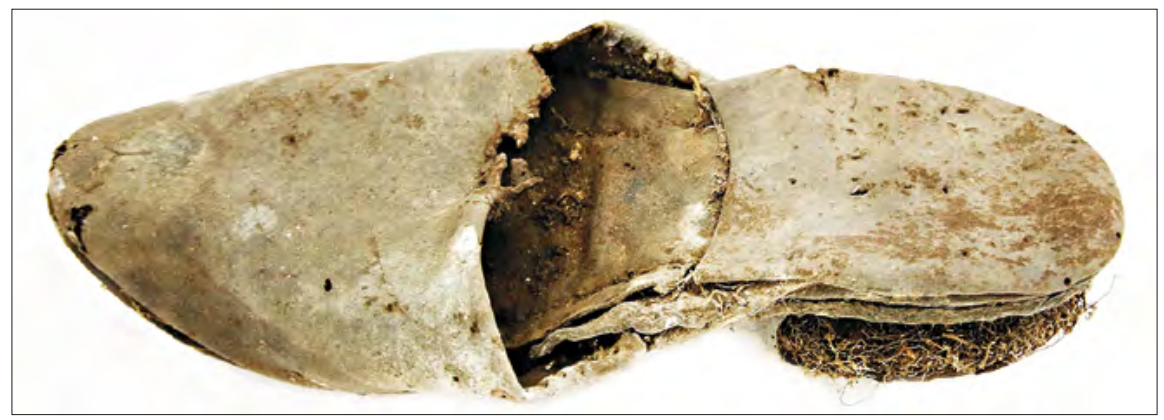

they could be worn over high-heeled shoes. They still had two purposes. On the one hand, they were used to protect delicate shoes made of soft leather or luxurious cloth (silk) and were frequently adjusted to their style, but on the other hand they served as separate home shoes. The upper could be made of colourful cloth (silk, wool) or delicate, soft leather, lined with cloth or another layer of leather. The sole was made of hard leather, and the heel was either wooden (Fig. 3) and covered with soft leather, or leather, sometimes made of even more than ten layers. There were lots of different possibilities and variants, which is proved by seventeenth-century and eighteenth-century museum collections not only in Poland but also abroad (Durian-Ress 1991: 70-73; Pratt, Woolley 2008: 48; Drążkowska 20II: 235-275). Textile shoes became highly popular in the eighteenth century (Kulesz 2019: 164-167), and their mass production started. It can be assumed that both full textiles shoes and openback mules were similar in structure, and they were worn by both men and women.

\section{A description of the shoes from Piaseczno}

The general state of preservation is good. The condition of the leather on the soles, heels, and uppers indicates that the shoes were intensively used when their owner was alive. There is no difference in cut between the left and the right shoe, however, deformations resulting from wearing allow to say which shoe was worn 


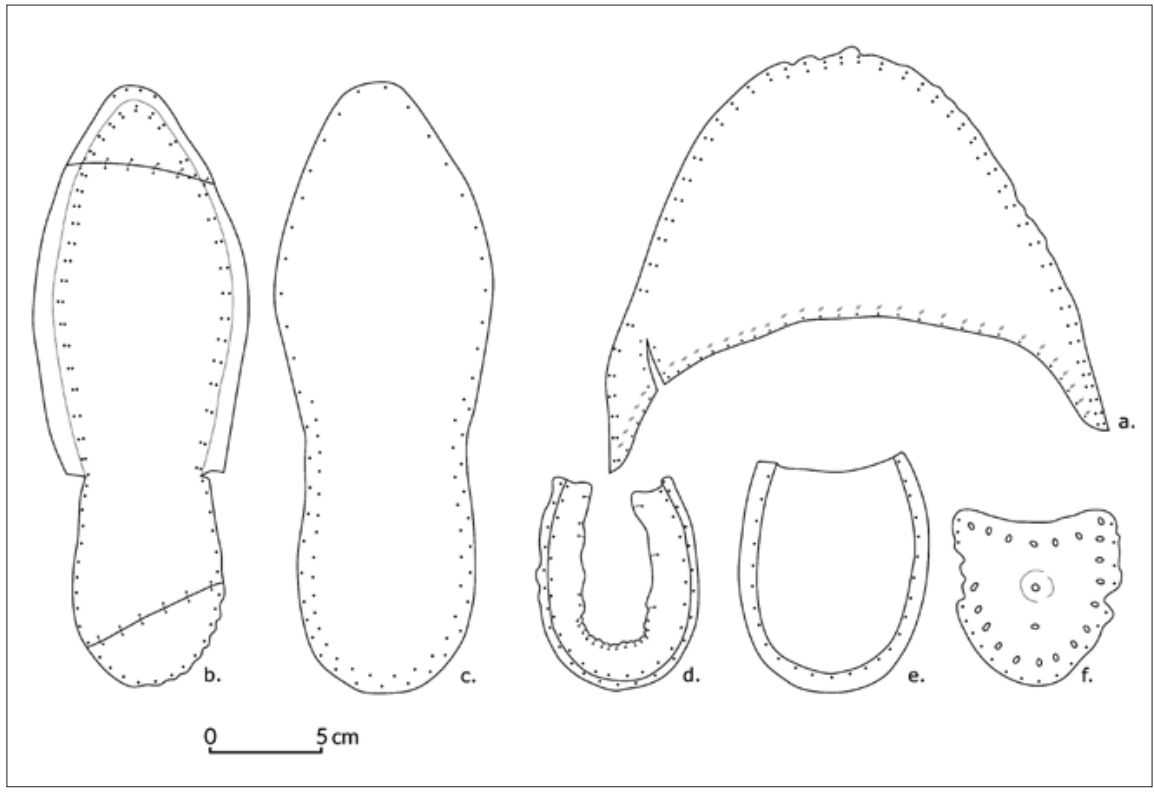

Fig. 5. Piaseczno. Shoe elements: a. the upper; b. the undersole; c. the sole; d. the strap; e. the external heel counter; f. the heel layer (prepared by A. Kulesz).

on which foot. The left shoe has been preserved almost whole (Fig. 4). All leather components of the shoe were identified (Fig. 5): the sole, the undersole, the upper, the external heel counter, the strap, and heel layers. The right has been preserved in part (the sole, the undersole, the heel counter, the strap - torn in half, and a fragment of the upper).

The sole (Fig. 5c)

The right and the left soles are identical, symmetrical in shape. An almond-shaped toe, a symmetrical forefoot, a midfoot slightly undercut on both sides, a rounded heel. There are cuts on the underside of the sole at the midfoot, which were to make leather in this part of the shoe more flexible. A part of the stitch at the heel on the underside of the sole is oblique, which protected it from leaking. Dimensions: length $-282 \mathrm{~mm}$, forefoot width $-98 \mathrm{~mm}$, midfoot width $-70 \mathrm{~mm}$, heel width $-75 \mathrm{~mm}$.

The undersole (Fig. $5 \mathrm{~b}$ )

The undersole was made of three fragments. Smaller fragments that formed the toe and the heel were joined diagonally with the main part of the undersole. They were joined with a running stitch (Fig. 6), but fragments were also 


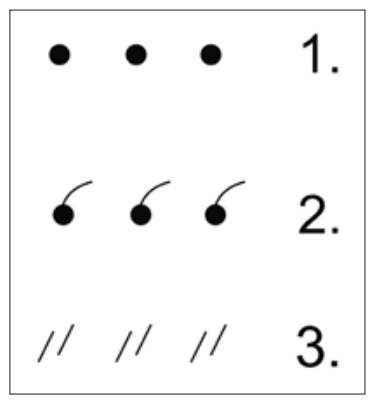

Fig. 6. Stitch marks: 1. double-needle straight stitching; 2. one-needle perpendicular stitching; 3. stitching marks in the leather (as called in Blusiewicz 2009: 45).

placed so that they contacted one another. At the toe and at the forefoot, the undersole was stitched directly to the sole and the upper, while at the heel and at the midfoot, elements were joined with a strap. The shape of the undersole at the midfoot and at the toe is widened by a rim that did not serve any structural purposes but only concealed and sealed stitches from the inside, thanks to which wearing the shoe was more comfortable. Dimensions: length $-263 \mathrm{~mm}$, forefoot width $-92 \mathrm{~mm}$, midfoot width $-62 \mathrm{~mm}$, heel width $-65 \mathrm{~mm}$.

The strap (Fig. 5d)

A structural element that allowed to sew the sole and the undersole together at the heel. Width $-20 \mathrm{~mm}$.

Heel layers (Fig. sf)

The heel of the left shoe consisted of six full layers. They were joined in the centre, most probably with a nail, and additionally along the edge with wooden dowels with ellipsoidal cross-section. The upper layers of the heel were joined not only with dowels but also with a stitch along the edge. Elements of the heel were made of leather offcuts or reused fragments. Some of the layers consisted of two elements sewn together. Dimensions: length $-83 \mathrm{~mm}$, width - approx. $70 \mathrm{~mm}$.

\section{Heel counter (Fig. se)}

It was an element improving the comfort of use and aesthetic qualities of the heel and the midfoot of the shoes. It concealed all stitches joining the undersole with the sole. The counter was connected with the outer edge of the undersole. Dimensions: length $-96 \mathrm{~mm}$, midfoot width $-64 \mathrm{~mm}$, heel width $-8 \mathrm{I} \mathrm{mm}$.

\section{The upper (Fig. sa)}

The upper is rather full, with a rather shallow cut-out. Leather along the cutout was folded and oversewn, which protected its edge from damage. On the outer surface there are clear marks of animal blood vessels, which means it was made of the flesh side of leather, the structure of which resembles suede. On the inside, there was an imprint of fabric, perhaps lining. 


\section{Characteristics of the shoes from Piaseczno}

Considering their rather delicate structure and size, the items found in Piaseczno can be classified as home shoes worn in the second half of the eighteenth century. Such pantables were worn in the privacy of one's home, while relaxing or receiving trusted guests, and sometimes also symbolised an informal character of meetings outside (Pratt, Woolley 2008: 40).

Home shoes were frequently elements of a night set, along with a nightshirt and a nightcap (Pratt, Woolley 2008: 40). Probably, they were often comfortable elements of the robe de chambre popular at the time, called rubdeszan in Poland (Dudziński et al. 2015: 54-55).

Perhaps the uppers of the pair of shoes in question were covered with decorative fabric. This is indicated by numerous prick marks on their surface, which could have been left by the thread joining the leather part with the textile one. Moreover, the threads of the shoes are finished rather sloppily, which may indicate that they were originally covered.

It has to be noted that concealing the threads of the sole obliquely prepared the shoes to be worn outside, protecting them from absorbing too much moisture, but it does not mean that they were worn over other footwear.

The structure of the open-back shoes found in Piaseczno resembles the pair of shoes from the grave of Rev. Kazimierz Jugowski, excavated during research in Gniew in 2013. The basic structure of the shoes was fully made of leather. An additional element was felt on the inside of the upper (Grupa et al. 20I4: 73, note I49). The priest died on January I4, 1726, so lined open-back shoes and thick woollen socks are not surprising elements of the grave goods. The felt insulating the upper was so loose that it was necessary to add a textile lining. Unfortunately, this element has not been preserved, so it can only be presumed that it was linen or woollen fabric.

Known Polish materials include a few examples of similar shoes from Gdańsk and Elblagg. Each of them has some individual characteristics. It may be an upper edged with a decorative trim or ornamented surface. The size of these shoes differ (Każdy krok... 2016: 103-110). The shoe from Elbląg was made of thick leather. It is large and its graceless form may indicate it was an overshoe (Drążkowska 20II: 220-22I). If these assumptions are correct, it would be another form of a slipper with a heel of leather layers and a thick sole reinforced with a few layers of leather at the midfoot.

\section{Conclusions}

The pair of shoes found in Piaseczno and described in this paper represents a valuable contribution to the discussion on open-back shoes. It should be noted that finding a pair of shoes in archaeological material is rare. So far, such finds have only come from graves. Urban accumulations usually offer isolated artefacts. 
When interpreting such finds, the basic difficulty is the determination of their function. In specific circumstances, functions of overshoes and home shoes could to a certain extent overlap. However, it seems that in the modern era separate pairs of shoes were made to serve these different purposes. Unfortunately, the only evidence that would allow to lean towards one of the options involves the categories of massiveness and size of the shoes, and the diversity of the materials used.

The issue of nomenclature is equally complicated. The paper uses a number of names for open-back shoes (pattens, mules, chopines, slippers, pantables) to reflect the linguistic richness. Undoubtedly, different designs used to have their own names. Perhaps the etymology of the names listed would offer some suggestions. However, this should be a subject of further research. The issue requires careful studies, but as it was already mentioned, last wills and testaments and posthumous inventories from the seventeenth and eighteenth centuries rarely include shoes. One can once again quote a fragment of the last will and testament from the Halych Land, in which Piotr Wirozembski (I625) asks to be buried in specific clothes:

[...] After I die, dress my body first in a new shirt and long johns, an old Moravian dolman, a cap, fine clothes, baczmagi and slippers. This is all prepared with me. [...] (Klint et al. 2018: 107).

In this case, specific names of shoes were used - baczmagi, which were imported from Turkey (with toes curled up), and slippers. This suggests that slippers were to be worn over baczmagi. What should be emphasised is the fact that the most neutral term is the descriptive term 'open-back shoes'.

A good state of preservation of the shoes from Piaseczno, which allowed for reconstruction (Fig. 7) and analysis of the cutting and stitching, provides new

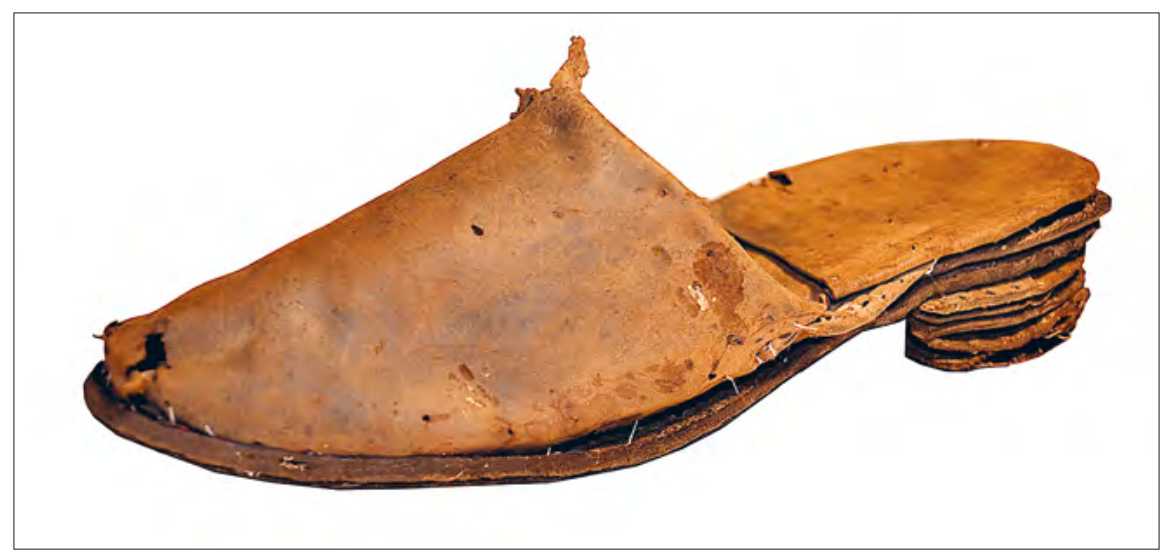

Fig. 7. Piaseczno. A reconstructed shoe (photograph by A. Kulesz). 
information about shoemaking techniques in the modern era. Studies of modern artefacts, long neglected by archaeologists, still include very few works concerning shoes. This perhaps results from the fact that these artefacts are to a large extent fragmentary. The Authors' observations indicate that graves usually only include leather soles and, at times, fragments of heels. They are most probably elements of textile shoes that are not immediately recognisable to archaeologists, and in most cases such information is only shared orally without any deep reflection.

\section{Bibliography}

Blusiewicz K. (2009), Warsaw Footwear in the I4 ${ }^{\text {th }}-18^{\text {th }}$ Century. From the Archaeological Collection in the Historical Museum of the City of Warsaw, [in:] Archeologia dawnej Warszawy, I, Muzeum Historyczne m. st. Warszawy, Warszawa.

Cassagnes-Brouquet S. (2009), La vie des femmes au Moyen Âge, Ouest-France, Rennes.

Ceynowa B. (2004), Późnośredniowieczne patynki gdańskie z badań na Wyspie Spichrzów, "Pomorania Antiqua", I9, p. I39-I53.

Ceynowa B. (2005), Patynki z badań na Wyspie Spichrzów w Gdańsku/Aus Untersuchungen an der Speicherinsel in Gdańsk (Danzig) stammende Pantoffeln, [in:] H. Paner, M. Fudziński (ed.), XIV Sesja Pomorzoznawcza, vol. II, Od wczesnego średniowiecza do czasów nowożytnych, Muzeum Archeologiczne, Gdańsk, p. 3I9-326.

Ceynowa B. (2009), Obuwie ochronne znalezione w Gdańsku-problematyka i metody badawcze, [in:] In gremio - In praxi. Studia nad średniowiecznym skórnictwem, Wydawnictwo IAiE PAN, Szczecin, p. 9-II2.

Cnotliwy E. (I994), Późnośredniowieczne obuwie ochronne z badań na Podzamczu w Szczecinie, "Materiały Zachodniopomorskie", 40, p. 20I-2IO.

Drążkowska A. (20II), Historia obuwia na ziemiach polskich od IX do końca XVIII wieku, Wydawnictwo Naukowe Uniwersytetu Mikołaja Kopernika, Toruń.

Dudziński T., Grupa M., Grupa D., Krajewska M., Majorek M., Nowak M., Nowak S., Przymorska-Sztuczka M., Wojciechowska A. (2015), Tajemnice szczuczyńskich krypt, vol. III, Towarzystwo Przyjaciół 9 Psk. Uniwersytet Mikołaja Kopernika, Grajewo-Toruń.

Durian-Ress S. (I99I), Schuhe. Vom späten Mittelalter bis zur Gegenwart, Hirmer, Munich.

Goubitz O., Driel-Murray van C., Groenman-van Waateringe W. (200I), Stepping through the Time. Archaeological Footwear from Prehistoric Times until I800, SPA Uitgevers, Zwolle.

Grew F., Neergaard de M. (200I), Shoes and Patterns. (Medieval Finds from Excavation in London), vol. II, London.

Grupa D. (2019), Laying Waste in Archaeological Sites. The Problems of Damage to Historical Sacred Objects as a Result of Human Activity, "Fasciculi Archaeologiae Historicae", 32, p. I89-I99, https://doi.org/IO.23858/FAH32.20I9.0I2

Grupa M. (20I2), Wetniane tekstylia pospólstwa i plebsu gdańskiego (XIV-XVII w.) i ich konserwacja, Wydawnictwo Naukowe Uniwersytetu Mikołaja Kopernika, Toruń. 
Grupa M. (20I8), Kultura materialna w świetle badań archeologicznych $w$ sanktuarium w Piasecznie, [in:] W. Pikor (ed.), Kultura materialna i duchowa sanktuarium w Piasecznie, Wydawnictwo "Bernardinum", Pelplin, p. 33-43.

Grupa M., Grupa D., Kozłowski T., Krajewska M., Majorek M., Nowak M., Nowak S., Przymorska-Sztuczka M., Wojciechowska A., Dudziński T. (20I4), Tajemnice szczuczyńskich krypt, vol. II, Towarzystwo Przyjaciół 9 PSK. Uniwersytet Mikołaja Kopernika, Grajewo-Toruń.

Grupa M., Kozłowski T., Jankauskas R., Grupa D., Krajewska M., Krakowska S., Majorek M., Mosiejczyk J., Nowak M., Nowak S., Przymorska-Sztuczka M., Wojciechowska A. (2015), Secrets of the Crypt in St. Ann's Chapel. Tajemnice krypty w kaplicy św. Anny, Stowarzyszenie Centrum Aktywnych, Gniew.

Gutkowska-Rychlewska M. (1968), Historia ubiorów, Państwowe Wydawnictwo Szkolnictwa Zawodowego, Warszawa.

Każdy krok zostawia ślad. Obuwie historyczne ze zbiorów Muzeum Archeologicznego $w$ Gdańsku. Katalog wystawy (20I6), Muzeum Archeologiczne, Gdańsk.

Klint P., Rzemieniecki K., Węglorz J. (2018), Źródta szlacheckie z ksiag grodzkich i ziemskich ziemi halickiej zXVII wieku, Wydawnictwo Uniwersytetu Wrocławskiego, Wrocław.

Kulesz A. (2019), Women's Shoes from the Crypt of the Church of the Name of the Holy Virgin Mary in Szczuczyn, Podlaskie Voivodship, "Analecta Archaeologica Ressoviensia", I4, p. I55-I68, https://doi.org/IO.I5584/anarres.20I9.I4.II

Pescio C. (20I7), Malarstwo holenderskie. Ztoty wiek, Wydawnictwo Arkady, Warszawa.

Pratt L., Woolley L. (2008), Shoes, V\&A Publishing, London.

Sikora R., Szleszyński R. (20I4), Husaria Rzeczypospolitej, Warszawa.

Swann J. (1982), Shoes, Batsford LTD, London.

Turnau I. (1983), Polskie skórnictwo, Zakład Narodowy im. Ossolińskich, Wrocław.

Wywrot-Wyszkowska B. (2002), Późnośredniowieczne patynki z lokacyjnego Kotobrzegu, "Przegląd Archeologiczny", 50, p. IO3-IIO.

Wywrot-Wyszkowska B. (2008), Skórnictwo w lokacyjnym Kotobrzegu. XIII-XV wiek, Instytut Archeologii i Etnologii pan, Szczecin.

Zimmerman H. (2007), Textiel in context. Een analyse van archeologische textielvondsten uit sbe-eeuws Groningen, Stichting Monument \& Materiaal, Groningen.

\section{Summary}

\section{Open-back Shoes from the Southern Crypt in Piaseczno, Pomerania Province}

A discussion on modern shoes is limited on account of the scarcity of sources provided by archaeological research. This gap is to a certain extent filled by museum collections and iconography. This is why it is so important to publish new finds as one can only initiate discussion on isolated artefacts of open-back shoes based on such publications. Such a pair was found in the southern crypt of the Church of the Nativity of the Blessed 
Virgin Mary in Piaseczno. These are unique objects as it is possible to identify all their elements and to determine the quality of leather, which was rather thick. Their general state of preservation is good. The condition of the leather on the soles, heels, and uppers indicates that the shoes were intensively used when their owner was alive. There is no difference in cut between the left and the right shoe, however, deformations resulting from wearing allow to say which shoe was worn on which foot.

The pair of shoes found in Piaseczno and described above represents a valuable contribution to the discussion on open-back shoes. When interpreting such finds, the basic difficulty is the determination of their function. In specific circumstances, functions of overshoes and home shoes could to a certain extent overlap. However, it seems that in the modern era separate pairs of shoes were made to serve these different purposes. Unfortunately, the only evidence that would allow to lean towards one of the options involves the categories of massiveness and size of the shoes, and the diversity of the materials used.

The paper uses a number of names for open-back shoes (pattens, mules, chopines, slippers, pantables) to reflect the linguistic richness. There is no doubt that different designs used to have individual names, however, the scarcity of accounts makes it very difficult to reconstruct the linguistic reality of old.

Keywords: open-back leather shoes, pantables, mules, slippers, eighteenth century, Piaseczno, Poland

\section{Streszczenie}

\section{Obuwie z wolnq̨ piętą z południowej krypty w Piasecznie, woj. pomorskie}

Dyskusja na temat nowożytnego obuwia jest dość ograniczona ze względu na szczupłość źródeł pozyskiwanych w czasie badań archeologicznych. Jednak tę lukę uzupełniają w jakiejś mierze kolekcje muzealne i ikonografia. Dlatego tak istotne jest publikowanie kolejnych znalezisk, bo tylko w oparciu o nie można podjąć dyskusję na temat pojedynczych egzemplarzy obuwia z wolną pietą. Taka właśnie para została znaleziona w południowej krypcia kościoła pw. Narodzenia Najświętszej Marii Panny w Piasecznie. Należy ona do unikatowych obiektów, ponieważ można określić jej wszystkie elementy oraz jakość skóry, która raczej należała do grubych. Ogólny stan zachowania obuwia można określić jako dobry. Powierzchnia skóry na podeszwach, obcasach oraz przyszwach świadczy o intensywnym użytkowaniu wyrobu za życia właściciela. Zostały one wykonane bez rozróżnienia kroju dla prawej i lewej stopy, ale odkształcenia wynikające ze znoszenia pozwalają ocenić, który pantofel noszono, na której stopie.

Opisywana powyżej para pantofli odnaleziona w Piasecznie stanowi ciekawy przyczynek do dyskusji na temat obuwia z wolną piętą w ogóle. Podstawową trudność w interpretacji takiego znaleziska może sprawiać określenie funkcji, jaką pełniło. Funkcje obuwia ochronnego i obuwia domowego do pewnego momentu lub w specyficznych okolicznościach mogły przenikać się. Jednak wydaje się, że w czasach nowożytnych konstruowano oddzielne pary obuwia służącego jednym i drugim celom. Niestety, jedynymi przesłankami pozwalającymi skłaniać się ku którejś z tez są raczej subiektywne kategorie masywności i wielkości obuwia oraz różnorodność zastosowanych surowców. 
W artykule posłużono się szeregiem określeń obuwia z wolną piętą (patynki, mule, mulety, kapcie, pantofle), by unaocznić bogactwo językowe. Z pewnością w latach minionych określone modele miały swoje nazwy, niestety szczupłość przekazów nastręcza wielkie trudności w rekonstruowaniu dawnej rzeczywistości językowej.

Słowa kluczowe: skórzane obuwie z wolną piętą, mule, pantofle, kapcie, XviıI w., Piaseczno, Polska

\author{
Aleksandra Kulesz \\ Nicolaus Copernicus University in Toruń \\ Institute of Archaeology \\ Poland \\ e-mail: olina.kulesz@gmail.com
}

\title{
Małoorzata Grupa
}

Nicolaus Copernicus University in Toruń

Institute of Archaeology

Poland

e-mail: mgrupa@umk.pl 